\title{
PREDYSPOZYCJE AFEKTYWNE A OBRAZ CHOROBY PRZEWLEKŁEJ
}

\section{AFFECTIVE DISPOSITION AND CHRONICLE ILLNESS PERCEPTIONS}

\author{
Maciej Krzysztof Załuski \\ Zakład Psychologii Zdrowia, Instytut Pielęgniarstwa i Położnictwa \\ Uniwersytet Jagielloński - Collegium Medicum
}

DOI: https://doi.org/10.20883/pielpol.2018.11

\section{STRESZCZENIE}

Wstęp. Ciągle otwarte pozostaje pytanie o sposoby podtrzymywania motywacji do leczenia u pacjenta chorego przewlekle. Pewnych informacji dostarcza pojęcie obrazu choroby i związków z poczuciem samoskuteczności. Ważnym czynnikiem kształtującym obraz choroby są indywidualne preferencje afektywne pacjenta.

Cel. Sprawdzenie powiązań występujących pomiędzy typem preferencji afektywnych pacjenta, indywidualnym obrazem choroby przewlekłej a poczuciem samoskuteczności.

Materiał i metody. Badanie dotyczyło 40 pacjentów leczonych z powodu reumatoidalnego zapalenia stawów (RZS). Obraz choroby poznano za pomocą autorskiego kwestionariusza powstałego w zgodzie z koncepcją Leventhala. Do zbadania preferencji afektywnych użyto kwestionariusza: Skala Uczuć Pozytywnych i Negatywnych - SUPIN - wersja C-30, natomiast poczucie skuteczności sprawdzono za pomocą Skali Uogólnionej Własnej Skuteczności-GSES.

Wyniki i wnioski. W badanej grupie przeważały osoby ze skłonnością do afektywności negatywnej o wysokim nasileniu oraz afektywności pozytywnej o niskim nasileniu. Zaobserwowano różnice w sposobach spostrzegania choroby przez pacjentów o odmiennych predyspozycjach afektywnych. Poczucie samoskuteczności różni się ze względu na obecny u pacjenta rodzaj afektywności pozytywnej.

SŁOWA KLUCZOWE: obraz choroby, zaburzenia afektywne, skuteczność własna, reumatoidalne zapalenie stawów.

\section{Wstęp}

W latach 60.-70. XX w. Leventhal prowadził badania nad zależnościami pomiędzy uzyskaniem przez człowieka informacji dotyczących zagrożenia zdrowia i życia a podjęciem zachowań prozdrowotnych. Wykorzystując zdobytą wiedzę w leczeniu pacjentów przewlekle chorych, zespół Leventhala skonstruował hierarchicznie zorganizowany model adaptacji człowieka do choroby. Celem było zwiększanie zaangażowania pacjenta w przebieg leczenia. Założono, iż ludzie mają wyobrażenia oraz wiedzę pojęciową na temat choroby własnej, jej przyczyn i następstw, a także możliwych do podjęcia

\begin{abstract}
Introduction. The question about ways of supporting motivation chronically ill patients still remains open. The illness perception construct and its connections with self-efficacy provide some information. Patient's individual affective disposition is an important factor of illness perception.

Aim. Checking connections between the type of affective disposition, individual illness perception, and self-efficacy.

Material and methods. 40 patients with rheumatoid arthritis (RA) participated in the survey. The author's questionnaire form in accordance with the Levental's model of illness was used. For examining affective disposition a SUPIN C-30 version questionnaire was used, the level of self-efficacy was checked with the GSES scale.

Results and conclusions. The group was dominated by persons with negative affective disposition with the high escalation, and by persons with positive affective disposition with the low escalations. Differences in the ways of illness perception by patients differing in affective disposition were observed. The account of self-efficacy is diversified by the patient's positive affective disposition type.
\end{abstract}

KEYWORDS: illness perception, affective disorders, self-efficacy, rheumatoid arthritis.

działań zaradczych. Koncepcja nazwana samoregulacyjnym modelem choroby i zdrowia połączyła w sobie elementy o charakterze informacyjnym, proceduralnym, kompetencyjnym i kontrolnym [1, 2], w sposób istotny kształtujące zachowania prozdrowotne człowieka. Wspomniane elementy tworzą: przekonania na temat osobistej podatność na zachorowanie, umysłowe strategie radzenia sobie z zagrożeniami ze strony choroby, a także własnymi reakcjami emocjonalnymi towarzyszącymi leczeniu, zdolność do podejmowania realistycznych działań prozdrowotnych i unikania zachowań ryzykownych, umiejętność bieżącej oceny skuteczności 
podejmowanych działań. Jak zauważają Cameron i Leventhal, funkcją samoregulacji jest formułowanie celów prozdrowotnych, planowanie odpowiednich sposobów ich osiągnięcia oraz ocena podejmowanych działań wraz z ewentualną rewizją celów i sposobów. Koncepcja podkreśla zasadniczą rolę poznawczej oraz emocjonalnej reprezentacji zdrowia i groźby choroby w umyśle człowieka, jako podstawy dla podejmowania zachowań prozdrowotnych. Autorzy zauważają, że ważna jest zarówno wiedza pacjenta na temat zagrożenia zdrowia oraz sposobów zabezpieczenia się, jak i obecne w nim emocje i sposoby polepszania samopoczucia. Leventhal zaproponował opis rozumienia choroby przez pacjenta za pomocą pięciu wymiarów dotyczących wyobrażeń i samowiedzy na temat: 1) tożsamości choroby, 2) czasu jej trwania, 3) przyczyny wystąpienia, 4) przewidywanych konsekwencji oraz 5) kontroli leczenia choroby [1]. Tożsamość choroby to inaczej jej etykieta, powstała na bazie oznak i objawów występujących z różnym nasileniem. Za jej pomocą pacjent wyraża poglądy na temat schorzenia. Czas trwania dotyczy przekonania o przewidywanym przebiegu choroby, o tym, czy jest chorobą postępującą ostro, a zarazem krótkotrwale, czy też chroniczną, nawracającą lub nieuleczalną. Przyczyny choroby to założenia o domniemanych źródłach zachorowania, wpływie genów, środowiska naturalnego lub własnych zachowań. To również znajomość mechanizmów odpowiedzialnych za utrzymywanie się schorzenia. Następstwa to sądy o zmianach w życiu pacjenta wywołanych faktem zachorowania, a dotyczących: sprawności fizycznej i psychicznej, możliwości wypełniania różnorakich ról życiowych. Kontrola wyraża założenia pacjenta na temat wpływu na przebieg leczenia oraz jego skuteczność.

Obraz choroby pozostaje pod wpływem szeregu czynników, do których należą cechy emocjonalne. Są wśród nich, ukształtowane na podłożu dziedzicznym i środowiskowym, predyspozycje do powtarzającego się przeżywania pozytywnych i negatywnych emocji o określonym natężeniu [3]. Emocje silnie oddziałują na procesy poznawcze i jakość czynności podejmowanych przez osobę chorą. Wyniki badań naukowych ukazują powiązania pomiędzy negatywną afektywnością a większym uwrażliwieniem pacjenta na obecność objawów somatycznych oraz tendencją do każdorazowego spostrzegania objawów w kategoriach poważnego zagrożenia zdrowia [4]. Indywidualnie zróżnicowana skłonność afektywna to zarówno typowe dla danego człowieka emocje wywołane sytuacją, jak i względnie stała cecha osobnicza. Z literatury wiadomo, iż niektórym chorobom somatycznym towarzyszą objawy przejściowych zaburzeń nastroju. W przypadku reumatoidalnego zapalenia stawów (RZS) zaburzenia psy- chiczne rozpoznawane są u 63\% pacjentów [5, 6]. Objawy depresyjno-lękowe mogą być wywołane działaniem czynników biologicznych. Ich występowanie tłumaczy się obecnością długo utrzymującego się wysokiego stężenia cytokin prozapalnych. Inną przyczyną obecności wspomnianych objawów są zaburzenia funkcji osi neuroendokrynnych (np. niedoczynność tarczycy), które mają działanie anksjogenne. Do najczęściej rozpoznawanych objawów szeroko rozumianych zaburzeń emocjonalnych w chorobach autoimmunologicznych, do jakich należy RZS, zalicza się: zaburzenia nastroju, poczucie nieustannego zmęczenia, zaburzenia snu oraz zaburzenia nerwicowe [7].

Reakcje afektywne rozpatrywać można jako względnie stałą w czasie i stabilną preferencję osobniczą powiązaną z innymi cechami osobowymi i temperamentalnymi [8]. Stałe preferencje afektywne cechują się wzajemną niezależnością przeżywanych uczuć. Człowiek doświadczać może jednocześnie emocji należących do przeciwstawnych wymiarów afektywnych. Obecność smutku lub lęku nie wyklucza równoczesnego przeżywania nadziei lub oczekiwania. Jest to szczególnie istotne w przypadku, gdy człowiek zmaga się z sytuacją wywołującą naprzemiennie nadzieję i rozczarowanie, jak dzieje się w trakcie chorób przewlekłych. Podtrzymaniu motywacji do leczenia służyć może wzbudzanie w sobie emocji pozytywnych pomimo obecności rozczarowania, żalu i zmęczenia $[9,10]$.

\section{Cel pracy}

Przedstawione w artykule wyniki badań dotyczą zależności pomiędzy wiedzą o chorobie i osobowymi predyspozycjami afektywnymi. Wiedza psychologiczna pokazuje, że przeżywane przez człowieka nastroje, emocje i afekty modyfikują procesy myślenia i zachowanie w sposób ze sobą zgodny, uruchamiając wzorce reagowania odpowiadające sytuacji i doświadczanym emocjom [11]. Od obrazu choroby i leżących u jego podłoża emocji zależeć mogą podejmowane przez pacjentów zachowania prozdrowotne. Pierwsze z pytań badawczych postawionych w pracy dotyczyło współzależności pomiędzy predyspozycją osobniczą do częstego i intensywnego doświadczania pozytywnych i negatywnych emocji a obrazem choroby przewlekłej. Celem kolejnego było uzyskanie odpowiedzi, które ze składowych obrazu choroby są szczególnie wrażliwe na wpływ dominującego nastroju pacjenta. Ostatnią kwestią było sprawdzenie założenia o związku obrazu choroby z poczuciem własnej skuteczności [12].

\section{Materiał i metody}

Badanie przeprowadzono w roku 2016 w grupie 40 pacjentów z rozpoznaniem RZS leczonych w placów- 
kach medycznych na terenie Krakowa [13]. Kryterium doboru do grupy był wiek życia i płeć pacjentów. Większość, tj. 58\% osób zbadanych, stanowiły kobiety, 42\% to mężczyźni. W grupie przeważały osoby w wieku 46 lat i powyżej (50\%). Liczebność pozostałych grup wiekowych przedstawiała się następująco: $20 \%$ badanych było wieku 18-25 lat, 18\% - w wieku 26-35 lat i 12\% - w wieku 3645 lat. Procedura badawcza uzyskała akceptację Komisji Bioetyki, dyrekcji szpitali oraz zgodę każdego pacjenta.

W celu poznania obrazu choroby zgodnego z założeniami modelu Levethala zbudowano kwestionariusz zawierający pięć pytań na temat: 1) wielości doświadczanych objawów i stopnia ich nasilenia, 2) zakładanego czasu trwania leczenia, 3) stopnia zrozumienia przyczyn choroby, 4) siły konsekwencji zachorowania oraz 5) poczucia kontroli nad chorobą. Osoba badana odpowiadała, posługując się 10-punktową skalą typu Likerta o opisanych końcach. Niski wynik na skali oznaczał: brak objawów choroby, przewidywany krótki czas leczenia, brak zrozumienia przyczyn choroby, brak oddziaływania choroby na życie oraz brak kontroli nad chorobą. Teoretyczny zakres wyników zawiera się pomiędzy 0a10pktdlakażdejz pięciubadanych składowychobrazu choroby. Konstruując narzędzie, wzorowano się na Brierf IIIness Perception Questionnaire [14]. Do zbadania cech afektywnych zastosowano Skalę Uczuć Pozytywnych i Negatywnych - SUPIN - wersja C-30 [3]. Narzędzie tworzy lista 30 przymiotników - 15 związanych z emocjami pozytywnymi i 15 - z negatywnymi. Zadaniem badanego jest oszacowanie nasilenia zazwyczaj doświadczanych emocji poprzez ocenę każdego przymiotnika na 5-punktowej skali o opisanych końcach. Niski wynik wskazuje na brak emocji lub nieznaczne nasilenie. Teoretyczny zakres wyników każdego z dwóch wymiarów afektywnych mieści się pomiędzy 15 a 75 pkt. W celu pomiaru poczucia skuteczności zastosowano Skalę Uogólnionej Własnej Skuteczności - GSES [12]. Osoba badana ocenia 10 stwierdzeń, używając w tym celu skali 4-punktowej. Niski wynik sumaryczny jest wskaźnikiem poczucia małej samoskuteczności. Zakres teoretyczny GSES: $10-40$ pkt.

W badaniu użyto procedury korelacyjnej służącej analizie zmiennych i łączących je relacji [15]. Opracowując statystycznie wyniki, skorzystano z: współczynnika korelacji rang rho Spearmana, testu istotności różnic międzygrupowych U Manna-Whitneya, wskaźnika siły różnicy średnich d-Cohena. Analizy statystyczne wykonano za pomocą oprogramowania komputerowego Statistica 10,0. Istotność statystyczną przyjęto na poziomie $\mathrm{p}<0,05$.

\section{Wyniki}

Wstępem do omówienia wyników jest charakterystyka grupy ze względu na posiadane predyspozycje emocjonalne. Średnie wartości preferencji afektywnych zadeklarowane przez osoby badane wyniosły: afektywność pozytywna 36,35 pkt (SD = 8,02), negatywna 38,70 pkt $(S D=10,53)$. Są to wyniki na poziomie 3-4 stena (niski) w przypadku afektywności pozytywnej i 6-7 stena (średni i wysoki) w przypadku negatywnej. Minimalny wynik pomiaru afektywności pozytywnej przyjął wartość 18 pkt (1 sten), maksymalny 55 pkt (8 sten). Minimalny wynik pomiaru afektywności negatywnej osiągnął wartość 16 pkt (1-2 sten) natomiast maksymalny wartość 65 pkt (10 sten). Wyniki pomiaru afektywności pozytywnej i negatywnej nie korelowały ze sobą (rho $=0,025)$. Porównując wyniki znormalizowane, należy stwierdzić, że w badanej grupie obecne były osoby ze zdecydowanie większym nasileniem afektywności negatywnej w stosunku do pozytywnej (test $Z=4,93$; $p<0,000$ ). Jedynie $17,5 \%$ zbadanych osób uzyskało w skali pozytywnego afektu wyniki wysokie (7 sten i wyżej), podczas gdy 57,5\% osób - wyniki wysokie w skali negatywnego afektu. Z kolei $65 \%$ zbadanych uzyskało niskie (na poziomie 1-4 stena) wyniki afektywności pozytywnej. Dane różniły się ze względu na płeć osób badanych, ale wyłącznie w przypadku emocji negatywnych. Średnia dla kobiet wyniosła 39,13 pkt $(S D=11,57)$, dla mężczyzn - 38,11 pkt $(S D=9,25)$; $Z=2,11, p<0,03$ (test serii Walda-Wolfowitza). Jednak ze względu na mało liczną grupę badawczą w dalszej analizie nie uwzględniono zmiennej płci.

Zmienną zależną w przeprowadzonym badaniu był obraz choroby wyrażony w postaci charakterystyki liczbowej pięciu składowych. Uzyskane dane przedstawiono na rycinie 1. Pacjenci spostrzegali chorobę raczej realistycznie, jako schorzenie „na zawsze”, któremu towarzyszy nagromadzenie silnych objawów. Największe różnice wewnątrzgrupowe ujawniły się w ocenie nasilenia objawów choroby (zakres rzeczywisty: 2-10 pkt) i stopnia zrozumienia jej przyczyn (zakres rzeczywisty: 1-10 pkt) oraz w oszacowaniu siły kontroli nad chorobą i leczeniem (zakres rzeczywisty: 0-10 pkt). Pacjenci najbardziej zgodni byli w przekonaniu, że choroba ciężko oddziałuje na ich życie i wymaga długotrwałego leczenia. Jeśli chodzi o współzależności pomiędzy elementami obrazu choroby, zaobserwowano, iż osoby deklarujące wyższe poczucie kontroli choroby zgłaszały wyższy stopień zrozumienia jej przyczyn (rho = 0,31; $p<0,05)$ oraz obecność mniej nasilonych objawów (rho = -0,32; $p<0,05$ ). Pacjenci przekonani co do znajomości przyczyn choroby i jej mechanizmów byli skłonni w większym stopniu traktować ją jako schorzenie przewlekłe (rho $=0,30, p<0,05)$. 


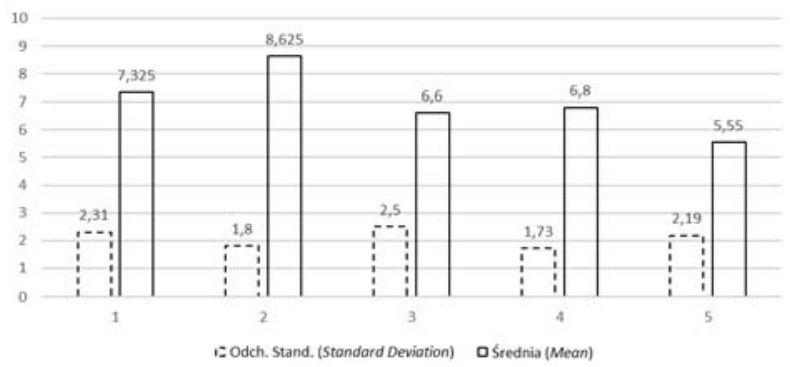

1 - nasilenie objawów choroby/ (tożsamość choroby)/intensity of the illness symptoms (identity of disease); 2 - szacunkowy czas leczenia/ timeline; 3 - stopień zrozumienia przyczyn choroby/meaning of the illness cause; 4 - stopień oddziaływania choroby na życie/consequences of the illness; 5 - poczucie kontroli nad chorobą i leczeniem/illness and treatment control. Teoretyczny zakres wyników od 0 do 10 pkt/Theoretical range of test results from 0 to 10 points

Rycina 1. Charakterystyka opisowa składowych obrazu choroby w badanej grupie

Figure 1. Descriptive statistics of illness perception elements

Źródło: opracowanie własne

Source: author's own analysis

Chcąc poznać zależności występujące pomiędzy preferowaną postacią afektywności a obrazem choroby, wyodrębniono z grupy badanych wyniki pochodzące od osób deklarujących skrajne nasilenie na dwóch wymiarach afektywnych. Powstały trzy podgrupy: 1) utworzona przez osoby z predyspozycją do przeżywania emocji pozytywnych o dużym nasileniu (powyżej 7 stena), 2) osoby z predyspozycją do intensywnego przeżywania emocji negatywnych (powyżej 7 stena), 3) osoby przeżywające emocje pozytywne z najmniejszym nasileniem (poniżej 3 stena). Średnia siła emocji pozytywnych w pierwszej podgrupie wyniosła $47,63 \mathrm{pkt}$ (SD $=4,24$, zakres rzeczywisty: 43-54 pkt), emocji negatywnych w drugiej podgrupie $-44,00$ pkt (SD $=8,80$, zakres rzeczywisty: 35-65 pkt). Średnie nasilenie emocji pozytywnych w trzeciej podgrupie przyjęło wartość 32 pkt (SD = 5,61; zakres rzeczywisty: 18-48 pkt). Grupy były rozłączne, osoby zgłaszające wysoki poziom afektywności pozytywnej nie deklarowały wysokiego nasilenia emocji negatywnych i vice versa.

Na rycinie 2 przedstawiono profile trzech obrazów choroby, utworzonych przez: 1) pacjentów doświadczających pozytywnych emocji z dużym nasileniem, 2) pacjentów doświadczających pozytywnych emocjiz małym nasileniem oraz 3) pacjentów doświadczających negatywnych emocji z dużym nasileniem. Porównując wyniki z zachowaniem kolejności składowych obrazu choroby, stwierdzić należy, iż najwyższy poziom nasilenia objawów oraz najsłabsze poczucie kontroli nad chorobą i leczeniem zadeklarowali pacjenci z preferencją do doświadczania afektów pozytywnych o najniższym nasileniu. O najdłuższym leczeniu choroby, najlepszym rozumieniu jej przyczyn i mechanizmów oraz najsilniejszym poczuciu kontroli myślały osoby z preferencją do afektywności pozytywnej o wysokim nasileniu. Natomiast pacjentów ze skłonnością do doświadczania emocji negatywnych z dużym nasileniem różniło od pozostałych oczekiwanie relatywnie najkrótszego czasu trwania leczenia. Wyliczone współczynniki d-Cohena wykazały występowanie dużego i średniego efektu różnicy między badanymi podgrupami. Największa różnica dotyczyła oceny poczucia kontroli nad chorobą, nasilenia objawów choroby oraz stopnia jej oddziaływania na życie u osób ze skłonnością do przeżywania emocji pozytywnych o wysokim i niskim nasileniu (d-Cohena odpowiednio: 1,26 i 0,77, 0,42).

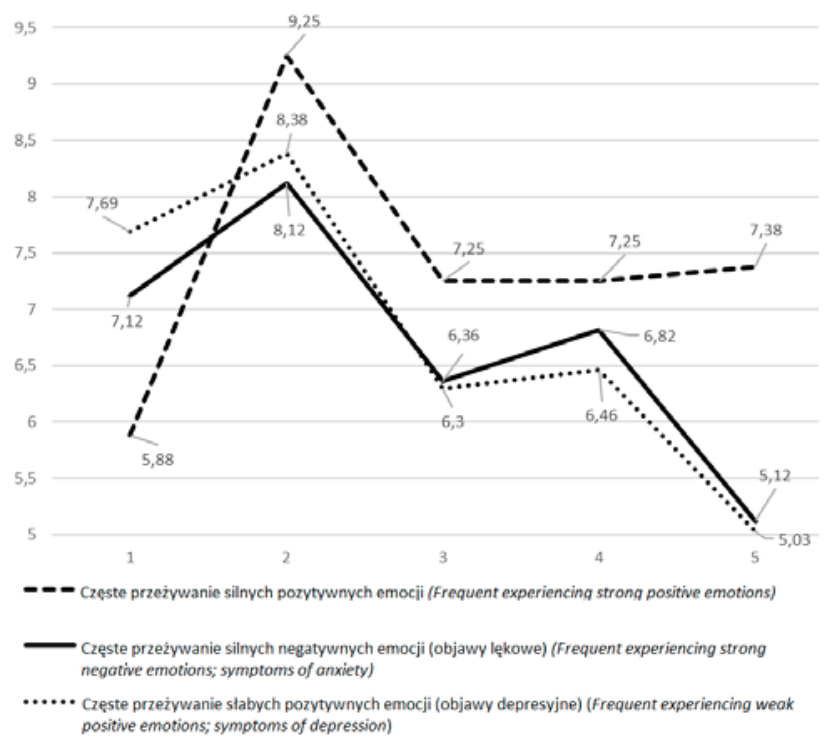

1 - nasilenie objawów choroby (tożsamość choroby)/intensity of the illness symptoms (identity of disease); 2 - szacunkowy czas leczenia/timeline; 3 - stopień zrozumienia przyczyn choroby/meaning of the illness cause; 4 - stopień oddziaływania choroby na życie/ consequences of the illness; 5 - poczucie kontroli nad chorobą i leczeniem/illness and treatment control. Teoretyczny zakres wyników od 0 do 10 pkt/Theoretical range of test results from 0 to 10 points

Rycina 2. Profil obrazu choroby u pacjentów różniących się predyspozycjami emocjonalnymi

Figure 2. Profile of illness perception patients with different affect disposition

Źródło: opracowanie własne

Source: author's own analysis

Uśredniony wynik pomiaru poczucia skuteczności własnej w badanej grupie wyniósł 27,32 pkt (SD = 5,77). Jest to wartość średnia, zarówno w przypadku kobiet $(M=27,47 ; S D=5,38$; zakres rzeczywisty: $16-37$ pkt), 
jak i mężczyzn ( $M=27,11$; $S D=6,42$; zakres rzeczywisty: 15-39 pkt). Jeśli wyliczyć wartość omawianej zmiennej, uwzględniając rodzaj preferencji emocjonalnych, można zaobserwować istotne różnice międzygrupowe. Badani $z$ afektywnością pozytywną o wysokim nasileniu uzyskali w GSES 31,33 pkt (SD =6,02), natomiast osoby z dużym nasileniem afektywności negatywnej uzyskały 26,95 pkt $(S D=6,34)$. Osoby z afektywnością pozytywną o niskim nasileniu uzyskały wynik najniższy, to jest 26,42 pkt (SD = 5,81). Siła różnicy pomiędzy wynikami skrajnymi była duża (d-Cohena $=0,83$ ).

\section{Dyskusja}

Jak przedstawia się charakterystyka preferencji afektywnych osób z badanej grupy w porównaniu do innych badanych? Czy można założyć, iż osoby chorujące na RZS cechuje specyficzna skłonność afektywna? Wyniki pomiaru cech emocjonalnych porównano z uzyskanymi w trakcie badań walidacyjnych kwestionariusza SUPIN przeprowadzonych na grupie 365 losowo dobranych Polaków [3]. W badaniach populacyjnych uzyskano następujące wartości: średni wynik afektywności pozytywnej Polaków wyniósł 43,02 pkt $(S D=9,10)$, natomiast negatywnej - 33,78 pkt (SD = 12,67). Wyniki pacjentów z RZS różniły się znacznie zarówno pod względem wartości bezwzględnych, jak i stosunku emocji pozytywnych do negatywnych. U osób z RZS dominowała afektywność negatywna, na poziomie wyższym niż w populacji, natomiast afektywność pozytywna osiągnęła poziom niższy niż w populacji. Siła różnicy w wynikach okazała się szczególnie duża w zakresie emocji pozytywnych (d-Cohena $=0,78$ ), w przypadku emocji negatywnych - bliska przeciętnej (d-Cohena $=0,42$ ). A zatem wyniki badania sugerują, iż pacjentów leczonych z powodu RZS cechowała skłonność do dominacji afektu negatywnego nad pozytywnym oraz przeżywania emocji negatywnych z większym, a pozytywnych z mniejszym nasileniem niż losowo dobranych Polaków.

Z literatury wiadomo, iż niski poziom afektywności pozytywnej wiązać się może z występowaniem u człowieka oznak senności i powolności. Obecność wysokiego poziomu emocji pozytywnych uzewnętrznia się pod postacią wigoru, entuzjazmu, podekscytowania. Niska afektywność pozytywna współwystępuje z takimi objawami zaburzeń nastroju (zwłaszcza depresji), jak: ograniczenie lub brak zainteresowań, anhedonia i wycofanie społeczne. W przypadku afektywności negatywnej jej wysoki poziom wiąże się z nerwowością, napięciem i dystresem, a niski - z poczuciem spokoju i relaksu [16]. Negatywna afektywność o wysokim nasileniu współwystępuje m.in. z takimi cechami osobowymi, jak: lękliwość, brak akceptacji siebie, brak zarad- ności życiowej i pesymistyczne myślenie o przyszłości $[3,16]$.

Uzyskane wyniki porównano z wynikami badania grupy 72 Amerykanów leczonych z powodu RZS. Zaobserwowano wyraźne różnice. Amerykanie byli bardziej zgodni w ocenie, a przede wszystkim zgłosili przewage pozytywnego afektu o dużym nasileniu nad negatywnym $\left(\mathrm{M}_{\text {pozyt. }}=29,6 ; \mathrm{SD}_{\text {pozyt. }}=7,4 ; \mathrm{M}_{\text {negat. }}=15,5\right.$; $\mathrm{SD}_{\text {negat. }}=5,8$ ) (niższe wartości w porównaniu do badań polskich były efektem zastosowania krótszego - 20-elementowego - wariantu kwestionariusza SUPIN, w oryginalnej wersji nazywającego się The Positive and Negative Affect Schedule - PANAS [16]). Również 100 pacjentów skandynawskich leczonych z powodu chronicznego bólu pleców i kolan zgłosiło przewagę afektywności pozytywnej o dużym nasileniu $(\mathrm{M}=28,22$; $\mathrm{SD}=7,86)$ wobec negatywnej $(\mathrm{M}=19,76$; $\mathrm{SD}=7,82$; $\mathrm{d}$-Cohena $=1,08$ ) (także i $\mathrm{w}$ tym badaniu zastosowano 20-itemowy wariant kwestionariusza SUPIN) [17]. Stwierdzić zatem należy, iż zbadani pacjenci polscy ujawnili preferencje emocjonalne odmienne zarówno od losowo dobranych Polaków, jak i pacjentów leczonych z powodu tej samej choroby w USA i krajach skandynawskich. Pacjenci polscy byli natomiast podobni do grupy 60 Brytyjczyków leczonych ambulatoryjnie z rozpoznaniem RZS, których wyniki pomiaru cech afektywnych również ujawniały wyraźną przewage negatywnych emocji $\left(\mathrm{M}_{\text {pozyt. }}=17,16, \mathrm{SD}=6,56 ; \mathrm{M}_{\text {negat. }}\right.$. = 29,81, SD = 9,48; SUPIN wariant 20-itemowy) [18]. Charakteryzując psychologicznie omawiane grupy, stwierdzić można, iż zdominowały je osoby lękliwe, pełne napięcia wewnętrznego oraz raczej wycofujące się z życia i kontaktów społecznych. Należy jednak zauważyć, iż w żadnym z badań nie uwzględniono interakcji takich zmiennych, jak: upływ czasu od momentu rozpoznania choroby, wiek metrykalny i nasilenie objawów. Można przypuszczać, iż mogą one tłumaczyć występowanie opisanych różnic.

Znana jest rola, jaką w podejmowaniu i podtrzymywaniu aktywności przez człowieka odgrywa sposób interpretowania sytuacji, w jakiej się znajduje. Od procesów oceny poznawczej zależy poziom odczuwanego stresu oraz wybór zastosowanych działań zaradczych. Obraz choroby wyraża sposób oceny sytuacji chorobowej przez pacjenta. Zindywidualizowany zbiór informacji, przekonań, wyobrażeń i oczekiwań dotyczących choroby warunkuje postawę, jaką przyjmuje pacjent wobec dolegliwości i jej leczenia. Tworzą ją myśli na temat choroby, przeżywane emocje i podejmowane działania prozdrowotne. Wyniki przeprowadzonego badania wskazują, iż jednym z czynników osobowych warunkujących postać obrazu choroby może być względnie stała preferencja afektywna pacjenta. Dotyczy to 
zwłaszcza tych składowych wizerunku choroby, które są najbardziej wrażliwe na działanie emocji. Preferencje afektywne zróżnicowały wyniki oceny: poczucia kontroli nad postępami leczenia, nagromadzenia i nasilenia doświadczanych objawów, a także długości oczekiwanego czasu leczenia. Pacjenci z niskim poziomem energii życiowej i radości, przejaw względnie trwałych predyspozycji afektywnych, rozpoznawali większe nagromadzenie objawów, deklarowali niższy wpływ na chorobę oraz - podobnie jak osoby lękliwe - wyrażali niższy stopień zrozumienia przyczyn choroby i jej patomechanizmów. Podobnie myślą osoby z zaburzeniami depresyjnymi, nastawieniem hipochondrycznym i tzw. syndromem wyuczonej bezradności. Pacjenci z predyspozycjami do występowania silnych negatywnych emocji, a zarazem przeciętnego i niskiego nasilenia emocji pozytywnych również deklarowali słabsze poczucie kontroli choroby i mniejsze jej rozumienie. Z literatury wiadomo, iż wspomniany rodzaj afektywności występuje u osób często doświadczających napięcia wewnętrznego i lęku [3]. Obecność wysokiego poziomu napięcia i niepokoju skłania osoby chore do koncentracji na szybkim usunięciu jego źródeł z wykorzystaniem mechanizmów obronnych zaprzeczania. Pacjent unika myślenia o przyczynach i następstwach dolegliwości, osłabiając w ten sposób lęk i napięcie. W efekcie jego poziom zrozumienia choroby jest relatywnie niski, a czas leczenia - przesadnie skrócony. Z drugiej strony ze stałym występowaniem negatywnych emocji u człowieka wiąże się skłonność do rozpoznawania większej liczby poważnych objawów somatycznych, spostrzegania silniejszego, negatywnego wpływu objawów na codzienne funkcjonowanie. Negatywne emocje ogniskują uwagę człowieka na informacjach je potwierdzających nawet drogą ich zniekształcania. W wyniku kumulującego się stresu u wspomnianych osób zauważa się predyspozycję do zapadania na choroby przewlekłe. Tymczasem afektywność pozytywna ma moderujący wpływ na doznania bólowe i objawy depresyjne [19, 20]. Zbadani pacjenci z predyspozycją do doświadczania afektywności pozytywnej z wysokim nasileniem (najmniej liczebna podgrupa) deklarowali najbardziej realistyczny obraz choroby: wyższy stopień zrozumienia źródła schorzenia (bez względu na obiektywną prawdę), dostrzegali jej przewlekłość i długotrwałość leczenia, zgłaszali mniej objawów i o mniejszym nasileniu, zauważali u siebie silne poczucie kontroli objawów choroby i wpływu na jej leczenie.

W jaki sposób obraz choroby może przekładać się na podejmowane przez człowieka działania, a w ich następstwie zmiany poczucia samoskuteczności? Leventhal w samoregulacyjnym modelu choroby i zdrowia przekonuje, iż obecny u pacjenta obraz choroby bez- pośrednio oddziałuje na poziom poczucia samokontroli w obszarze zachowań prozdrowotnych. Jeśli pacjent kontroluje objawy choroby i przebieg leczenia, a zwłaszcza gdy czyni to w sposób skuteczny, rośnie u niego poczucie sprawstwa i nadzieja na wyzdrowienie [4]. Badania przeprowadzone wśród diabetyków podkreślają rolę, jaką w aktywności zdrowotnej odgrywa kontrola choroby związana z posiadaną wiedzą na temat schorzenia. Ponad połowa - 52\% - wariancji wyjaśniającej wypełnianie zaleceń lekarskich przez młodocianych pacjentów związana jest z posiadanymi przekonaniami prozdrowotnymi [21]. Od nich zależy kontrola stężenia glukozy, przestrzeganie diety i aktywność fizyczna. Ujawniony w badaniu średni poziom poczucia skuteczności własnej pacjentów z RZS był zdecydowanie niższy niż uzyskany w badaniach innych osób leczonych przewlekle. Wyniki badań własnych ( $M=27,32$ pkt; $S D=5,77)$ są zbliżone do uzyskanych od pacjentów dializowanych $(\mathrm{M}=27,16$; $\mathrm{SD}=4,91)$ oraz nieznacznie niższe od wyników pacjentów z cukrzycą ( $\mathrm{M}=28,43$; $\mathrm{SD}=5,35)$ [11]. Co istotne, wyniki pacjentów z RZS są niemal identyczne z uzyskanymi w badaniach normalizacyjnych GSES $(M=27,32 ; S D=5,31)$. Widać zatem, iż w odróżnieniu od innych grup pacjentów obecność przewlekłej choroby nie wywołuje u osoby chorej zintensyfikowania zachowań prozdrowotnych, inaczej niż np. w wypadku kobiet w trakcie leczenia choroby onkologicznej $(\mathrm{M}=32,46 ; \mathrm{SD}=4,96)$ [22]. Prawdopodobne przyczyny leżą w specyfice RZS i wynikających z niej procedurach leczniczych. Wiadomo, iż poczucie samoskuteczności tworzy się u człowieka wraz ze wzrostem kontroli podejmowanych działań, które w przypadku osoby chorującej na RZS służą nie tyle całkowitemu i trwałemu wyleczeniu, ile spowolnieniu przebiegu choroby, zabezpieczaniu przed powikłaniami i ograniczaniu wpływu objawów na codzienne funkcjonowanie pacjenta. Niemniej jednak uzyskane dane wskazują, iż przekonanie na temat kontroli pozostaje w związku z dominującym nastrojem pacjenta i jest niższe u osób o niskim poziomie afektywności pozytywnej. Wartość współczynnika d-Cohena = 0,83 wyliczona dla poziomu samoskuteczności osób z wysokim i niskim nasileniem afektywności pozytywnej ukazuje silny efekt różnicy. Należy zatem stwierdzić, że względnie stałe cechy emocjonalne, jakimi są pozytywna i negatywna afektywność, mogą kształtować poczucie kontroli zachowań prozdrowotnych, a tym samym doświadczenia samoskuteczności również u osób chorych przewlekle.

Jak wskazują wyniki badań innych pacjentów chorujących na RZS, ocena ich nastroju z wykorzystaniem dwuwymiarowego modelu pozytywnej i negatywnej afektywności lepiej opisuje doświadczenia emocjonalne niż model jednowymiarowy, w którym zmienną wyja- 
śniającą jest poziom depresji lub w przypadku, gdy pozytywna i negatywna afektywność traktowane są jako przeciwległe pozycje na jednowymiarowym kontinuum [23]. W jednym z badań nad preferencjami afektywnymi u pacjentów z RZS zmienną niezależną był rodzaj stosowanych sposobów radzenia sobie z chorobą. Korzystanie przez osoby badane z mało adaptacyjnych strategii radzenia sobie ze stresem choroby (np. dopominanie się większej dawki leków przeciwbólowych) współwystępowało z wysokim poziomem afektywności negatywnej i niskim pozytywnej. Stosowanie strategii bardziej adaptacyjnych (np. wykonywanie ćwiczeń rehabilitacyjnych) charakterystyczne było wyłącznie dla osób z wysokim poziomem pozytywnego afektu. Wyniki pokazują odmienne cele, jakie stawiają sobie pacjenci w zależności od reprezentowanego poziomu afektywności. Osoby z wyższym poziomem lęku widzą w objawach choroby oznaki poważnego zagrożenia zdrowia i stąd podejmują działania służące ich usunięciu. Oczekują w ten sposób ulgi w napięciu wewnętrznym, którego obecność jest charakterystyczna dla wspomnianego rodzaju afektywności. Osoby z wysokim poziomem pozytywnego afektu, a zarazem poczuciem kontroli nad chorobą, skupiają się na działaniach osadzonych w realności, podtrzymujących sprawność. Szukają okazji do zwiększenia poczucia kontroli, co podtrzymuje w nich pozytywne emocje. Osoby z niskim poziomem pozytywnego afektu, z uwagi na niski poziom energii i brak radości, są w mniejszym stopniu zainteresowane podejmowaniem wspomnianych działań.

\section{Wnioski}

Życie pacjenta z reumatoidalnym zapaleniem stawów wymaga umiejętności radzenia sobie z nawrotami choroby i okresami remisji, pojawianiem się szeregu zmian pozastawowych, lękiem przed całkowitą utratą samodzielności ruchowej, utratą pracy, a nawet ryzykiem przedwczesnej śmierci. Możliwości zmiany przebiegu choroby lub zatrzymania jej progresji są ograniczone w czasie do tzw. okna terapeutycznego. Leczenie, zwłaszcza wcześnie podjęte, zatrzymuje postępy choroby w procesie niszczenia stawów, a także może prowadzić do remisji lub spowolnienia zmian degeneracyjnych. Aby jednak tak się stało, pacjent powinien podtrzymywać w sobie motywację do leczenia, starając się postrzegać chorobę w realistycznym świetle. Pomaga umiejętność wzbudzania w sobie nadziei, zaangażowania, radości, niezależnie od przeżywanych emocji negatywnych. Wydaje się, iż jest to równie ważne, jak zdolność do kontrolowania lęku i napięcia.

1. Indywidualne skłonności afektywne mają odbicie w sposobach postrzegania przez pacjenta choroby przewlekłej.
2. Pacjenci z niskim nasileniem pozytywnej afektywności zgłaszają więcej objawów o dużej intensywności, niski poziom zrozumienia przyczyn i mechanizmów choroby oraz słabe poczucie kontroli nad schorzeniem i jego leczeniem.

3. Poziom afektywności pozytywnej różnicuje pacjentów ze względu na deklarowane poczucie skuteczności własnej.

\section{Piśmiennictwo}

1. Nerenz $D$, Leventhal $H$. Self-regulation theory in chronic ilIness. W: Burish T, Bradley L (red.). Coping with Chronic Disease Research and Applications. New York: Academic Press; 1983. 13-37.

2. Singh R. Psychological Model of Illness. Newcastle: Cambridge Scholars Publishing; 2011. 16-20.

3. Brzozowski P. Skala uczuć pozytywnych i negatywnych SUPIN. Polska adaptacja skali PANAS Davida Watsona i Lee Anny Clark. Podręcznik. Warszawa: Pracownia Testów Psychologicznych Polskiego Towarzystwa Psychologicznego; 2010.

4. Cameron L, Leventhal H, Love R. Trait anxiety, symptom perceptions, and illness-related responses among women with breast cancer in remission during a tamoxifen clinical trial. Health Psychol. 1998; 17: 459-469.

5. Jasiewicz A, Samochowiec J. Zaburzenia psychiczne w chorobach tkanki łącznej. Psychiatria. 2011; 8: 39-45.

6. Kwiatkowska B, Przygodzka M, Konopińska E, Dąbrowska J, Sikorska-Siudek K. Depresja u chorych na reumatoidalne zapalenie stawów. Reumatologia. 2011; 49: 138-141.

7. Celińska-Löwenhoff M, Musiał J. Zaburzenia psychiczne w chorobach autoimmunologicznych - problemy diagnostyczno-terapeutyczne. Psychiatria Pol. 2012; 66: 1029-1042.

8. Fajkowska M, Marszał-Wiśniewska M. Właściwości psychometryczne Skali Pozytywnego i Negatywnego Afektu - Wersja Rozszerzona (SUPIN-X). Wstępne wyniki badań w polskiej próbie. Prz Psychol. 2009; 52: 355-387.

9. Heszen I. Pozytywne emocje w negatywnych sytuacjach: skąd się biorą i jak zmieniają radzenie sobie. W: Heszen I, Życińska J (red.). Psychologia zdrowia w poszukiwaniu pozytywnych inspiracji. Warszawa: Wydawnictwo Szkoły Wyższej Psychologii Społecznej „Academica”; 2008. 139-150.

10. Lazarus R. Toward better research on stress and coping. Am Psychol. 2000; 55: 665-673.

11. Łukaszewski W, Doliński D. Mechanizmy leżące u podstaw motywacji. W: Strelau J (red.). Psychologia. Podręcznik akademicki. Tom 2. Gdańsk: GWP; 2000. 441-456.

12. Juczyński Z. Narzędzia pomiaru w promocji i psychologii zdrowia. Warszawa: Pracownia Testów Psychologicznych Polskiego Towarzystwa Psychologicznego; 2001.

13. Idec A. Obraz siebie i choroby własnej u pacjenta chorego na reumatoidalne zapalenie stawów. Nieopublikowana praca magisterska. Kraków: Uniwersytet Jagielloński - Collegium Medicum; 2016.

14. Broadbent E, Petrie K, Main J, Weinman J. The Brief IIIness Perception Questionnaire. J Psychosom Res. 2006; 60: 631-637.

15. Feruson G, Takane Y. Analiza statystyczna w psychologii i pedagogice. Warszawa: PWN; 2009. 33.

16. Smith T, Christensen A. Positive and negative affect in rheumatoid arthritis: increased specificity in the assessment of emotional adjustment. Ann Behav Med. 1996; 18: 75-78. 
17. Thong I, Jensen M. The buffering role of positive affect on the association between intensity and pain related outcomes. Scand J Pain. 2017; 14: 91-97.

18. Barlow J, Cullen L, Rowe I. Educational preferences, psychological well-being and self-efficacy among people with rheumatoid arthritis. Patient Educ Couns. 2002; 46: 11-19.

19. McAndrew LM, Mora PA, Quigley KS et al. Using the Common Sense Model of Self-Regulation to Understand the Relationship Between Symptom Reporting and Trait Negative Affect. Int J Behav Med. 2014; 21: 989-994.

20. Matcham F, Hotopf S, Chalder T. Psychological correlates of fatigue in rheumatoid arthritis: A systematic review. Clin Psychol Rev. 2015; 39: 16-29.

21. Starowicz-Filip A. Rola poznawczego obrazu własnej choroby w adaptacji do cukrzycy - charakterystyka zagadnienia i przegląd badań. Diabetol Prakt. 2009; 10: 92-100.

22. Rogala D, Mazur A, Maślińska M, Koper K, Wysocka J. Poczucie własnej skuteczności i strategie przystosowania do choroby u pacjentek z nowotworem narządu rodnego. Curr Gynecol Oncol. 2015; 13(3): 154-164.
23. Sturgeon J, Finan $P$, Zautra A. Affective disturbance in rheumatoid arthritis: psychological and disease-related pathways. Nat Rev Rheumatol. 2016; 12: 532-542.

Źródło finansowania: Praca nie jest finansowana z żadnego źródła. Konflikt interesów: Autorzy deklarują brak konfliktu interesów.

Adres do korespondencji:

Maciej Krzysztof Załuski

ul. Mikołaja Kopernika 25

31-501 Kraków

tel.: 124247286

e-mail: maciej.zaluski@uj.edu.pl

Zakład Psychologii Zdrowia, Instytut Pielęgniarstwa i Położnictwa

Uniwersytet Jagielloński - Collegium Medicum 